\title{
DAMPAK KEBIJAKAN TRADE REMEDY TERHADAP EKSPOR COATED PAPER INDONESIA KE AMERIKA SERIKAT MENGGUNAKAN MODEL ARIMA INTERVENSI
}

\author{
Impact of Trade Remedy Policy on Indonesian Coated Paper Exports Using \\ ARIMA Intervention Model
}

\author{
Diva Amadea, Siskarossa Ika Oktora \\ Politeknik Statistika STIS, Jl. Otto Iskandardinata No. 64C, Jakarta 13330, Indonesia \\ Email: siskarossa@stis.ac.id
}

Naskah diterima: 27/07/2020; Naskah direvisi: 04/02/2021; Disetujui diterbitkan: 21/05/2021; Dipublikasikan online: 15/07/2021

\begin{abstract}
Abstrak
Indonesia merupakan salah satu negara dengan hutan tropis terluas di dunia yang memiliki kekayaan sumber daya hutan dan keanekaragaman hayati di dalamnya. Salah satu komoditas ekspor unggulan Indonesia yang merupakan hasil hutan adalah kertas. Pada periode 20062018, volume ekspor kertas ke beberapa negara tujuan utama ekspor menunjukkan tren yang terus menurun termasuk ke Amerika Serikat. Penurunan volume ekspor kertas di beberapa negara tersebut terkait dengan masalah yang dihadapi industri kertas Indonesia, yakni pengenaan kebijakan trade remedy oleh Amerika Serikat terkait praktik dumping dan subsidi produk coated paper Indonesia. Penelitian ini bertujuan untuk menganalisis pengaruh dan besarnya dampak dari pengenaan trade remedy terhadap ekspor kertas Indonesia ke Amerika Serikat dengan model ARIMA Intervensi. Data yang digunakan dalam penelitian ini adalah volume ekspor kertas (coated paper) bulanan (kg) dari Januari 2006 hingga Desember 2018. Hasil penelitian menunjukkan bahwa pengenaan kebijakan trade remedy oleh Amerika Serikat berpengaruh signifikan menurunkan volume ekspor kertas Indonesia ke negara tersebut. Dampak pengenaan kebijakan trade remedy oleh Amerika Serikat terhadap produk ekspor coated paper Indonesia langsung dirasakan saat kebijakan diberlakukan yaitu pada bulan Januari 2010. Dampak penurunan terbesar terjadi pada bulan Maret 2010, dengan penurunan sebesar 5.015 ton atau mencapai 91,07\%. Dampak negatif dari kebijakan trade remedy terhadap ekspor kertas Indonesia ke Amerika Serikat berlangsung sepanjang waktu penelitian dan dapat menjadi permanen jika tidak dilakukan intervensi kebijakan. Kebijakan yang direkomendasikan diantaranya adalah penguatan Portal Satu Data Perdagangan sebagai bagian dari penguatan administrasi bukti-bukti khususnya substansi dari sisi hukum untuk membantah tuduhan yang diberikan. Peningkatan performa ekspor coated paper Indonesia juga dapat disiasati dengan mencari pasar ekspor nontradisional.
\end{abstract}

Kata Kunci: Trade Remedy, Ekspor Kertas, Model ARIMA Intervensi

\begin{abstract}
Indonesia is one of the countries with the largest tropical forest in the world, which has a wealth of forest resources and biodiversity. One of the main Indonesia export from forest products is paper. In 2006-2018, the paper volume export to several main export destination countries showed a downward trend, including the United States. The decline in the paper volume export in several countries is related to problems facing the Indonesian paper industry, which imposes a trade remedy policy by the United States regarding dumping practices and subsidies for Indonesian coated paper products. This study aims to analyze the effect and magnitude of the imposition of trade remedy on Indonesian paper exports using the ARIMA Intervention model. The data used in this study is the volume of monthly coated paper exports $(\mathrm{kg})$ from January 2006 to December 2018. The results show that the imposition of a trade remedy policy has a significant effect on reducing Indonesian paper exports. The impact of the trade remedy policy imposed by the United States on Indonesian coated paper exports
\end{abstract}


was immediately felt in January 2010. The highest decline occurred in March 2010, with a decrease of 5,015 tons or reaching $91.07 \%$. The negative impact of the trade remedy policy on Indonesia's paper exports to the United States lasts throughout the time of the study and is considered permanent if no policy intervention is made. Policy recommendations include strengthening the One Trading Data Portal as part of strengthening the evidence's administration, especially the substance of the law, to dispute the charge given. The permanent negative impact on the performance of coated paper exports to the United States can also be overcome by seeking nontraditional export markets

.Keywords: Trade Remedy, Coated Paper Exports, ARIMA Intervention Model

JEL Classification: F13, F68, C22

\section{PENDAHULUAN}

Indonesia merupakan negara agraris yang memiliki luas daratan 187,75 juta ha yang terdiri dari lahan tidak berhutan seluas 93,80 juta ha dan luas lahan berhutan 93,95 juta ha (Kementrian Lingkungan Hidup dan Kehutanan, 2018). Forest Watch Indonesia (2014), melaporkan bahwa Indonesia tercatat sebagai salah satu negara yang memiliki hutan tropis terluas di dunia yang memiliki kekayaan sumber daya hutan. Hutan Indonesia merupakan modal pembangunan nasional. Salah satu komoditas kehutanan yang berkontribusi pada pendapatan nasional adalah kayu. Indonesia merupakan salah satu negara eksportir kayu terbesar di dunia dengan nilai diperkirakan mencapai USD 5 miliar per tahun (Kementerian perindustrian, 2018).

Industri pulp dan kertas Indonesia memiliki kontribusi yang cukup besar terhadap perekonomian nasional.
Industri pulp dan kertas memiliki nilai ekspor tertinggi, diikuti oleh komoditas kayu, dan komoditas furniture (Forbil Institute, 2017). Pada tahun 2016, industri pulp dan kertas berada pada posisi ketujuh sebagai penyumbang devisa terbesar sektor non-migas, mencapai USD 3,79 miliar. Kemudian terjadi peningkatan hingga USD 7,12 miliar pada tahun 2018 (Kementerian Perindustrian, 2018). Ekspor pulp dan kertas Indonesia juga memberikan kontribusi yang cukup tinggi terhadap Produk Domestik Bruto (PDB) di tahun 2018, yakni mencapai $17,6 \%$ terhadap total PDB industri pengolahan nonmigas, dan 6,3\% terhadap total PDB industri pengolahan. Jumlah industri pulp dan kertas nasional mencapai 84 perusahaan dengan kapasitas produksi kertas sebesar 16 juta ton/tahun dan produksi pulp sebesar 11 juta ton/tahun (Kementerian Perindustrian, 2018).

Negara tujuan utama ekspor kertas Indonesia diantaranya adalah 
Amerika Serikat, Australia, Jepang, Malaysia, dan Tiongkok. Berdasarkan Gambar 1. ekspor produk kertas Indonesia dari tahun 2006-2018 ke negara-negara tujuan utama relatif berfluktuasi. Dari negara-negara tujuan utama tersebut, ekspor kertas Indonesia ke Tiongkok cenderung memiliki tren yang meningkat. Sementara, ekspor kertas Indonesia ke Australia dan Malaysia cenderung stabil, sedangkan ekspor kertas Indonesia ke Amerika Serikat dan Jepang cenderung memiliki tren yang menurun.

Penurunan volume ekspor kertas di beberapa negara tersebut terutama terkait dengan masalah yang dihadapi industri kertas dan pulp Indonesia, yakni pengenaan kebijakan trade remedy oleh Amerika Serikat terkait praktik dumping dan subsidi produk coated paper Indonesia.

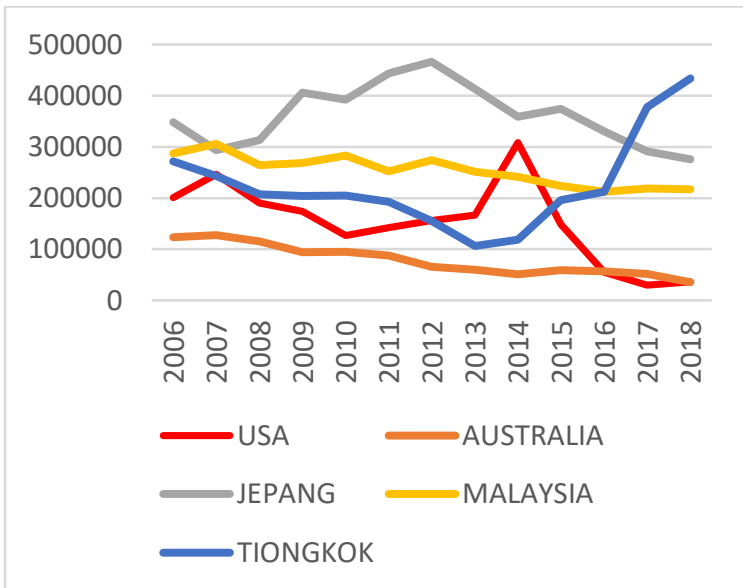

Gambar 1. Volume Ekspor Kertas Indonesia ke Negara Tujuan Utama (Ton) Sumber: UN Comtrade
Trade remedy adalah suatu kebijakan perdagangan yang dapat digunakan pemerintah untuk melindungi industri dalam negeri karena pengaruh Ionjakan produk impor. Instrumen ini merupakan instrumen yang diizinkan oleh World Trade Organization (WTO) yang dapat digunakan untuk melindungi industri dalam negeri akibat praktik perdagangan yang tidak sehat dari suatu negara. Instrumen trade remedy diantaranya, anti-dumping action dan countervailing duty measures.

Anti-dumping action atau bea masuk anti-dumping (BMAD) merupakan pengenaan bea masuk tambahan terhadap produk impor yang harga jual ekspornya diyakini lebih rendah dari harga jual normal di negara pengekspor sehingga menyebabkan kerugian terhadap industri dalam negeri. Countervailing duties (CVD) atau tindakan anti-subsidi adalah tindakan dengan menaikkan bea masuk karena negara pengekspor memberikan subsidi kepada produk yang diekspor, misalnya subsidi input atau kredit sehingga harga ekspor produk tersebut lebih murah dibanding produk dalam negeri.

Menurut Ningrum (2006), perkembangan ekspor kertas Indonesia cenderung memiliki tren yang meningkat dari tahun ke tahun. Namun, 
apabila ditinjau kembali dalam sepuluh tahun terakhir volume ekspor coated paper berfluktuatif dan cenderung memiliki tren yang menurun. Kementerian Perdagangan (2015) mendefinisikan coated paper sebagai kertas yang permukaannya dilapisi suatu senyawa tertentu yang bertujuan untuk meningkatkan tampilan cetak dari suatu kertas. Terdapat berbagai macam tampilan lapisan, seperti kusam, gloss, dan matte. Kelebihan dari coated paper adalah dapat menghasilkan gambar yang lebih tajam dan lebih terang, dan juga memiliki reflektivitas yang lebih baik dibandingkan jenis kertas lainnya

Secara umum sejak tahun 2010, ekspor coated paper Indonesia ke Amerika Serikat mengalami penurunan yang signifikan, yang diduga karena pengenaan CVD dan BMAD oleh Amerika Serikat terhadap ekspor coated paper Indonesia. Menurut Pusat Kebijakan Perdagangan Luar Negeri Kementerian Perdagangan, Amerika Serikat mengenakan CVD pada ekspor coated paper Indonesia sebesar $17,94 \%$ dan BMAD sebesar $20,13 \%$.

Menurut Pusat Kebijakan Perdagangan Luar Negeri Kementerian Perdagangan, pengenaan kebijakan trade remedy pada coated paper mengakibatkan Indonesia berpotensi kehilangan ekspor coated paper ke Amerika Serikat sekitar USD 50 juta per tahun. Hal ini ditunjukkan pada nilai ekspor coated paper tahun 2017 sebesar USD 3,5 juta. Selain itu, volume ekspor coated paper ke Amerika Serikat menurun sebesar $21,2 \%$ dan pangsa ekspor coated paper ke Amerika Serikat menurun mencapai 51\% di tahun 2017 dari tahun sebelumnya.

Penelitian terkait ekspor produk kertas Indonesia yang dikenai kasus trade remedy pernah dilakukan oleh Desembrico (2019) serta Beaulieu dan Prévost (2020). Kedua penelitian ini mencoba untuk menelaah putusan WTO dan akibat hukum terkait sengketa produk coated paper terhadap perdagangan internasional. Dengan menggunakan metode yuridis normatif melalui pendekatan perundangundangan, hasil penelitian ini menyimpulkan bahwa Indonesia telah terbukti melanggar ketentuan Perjanjian Anti Dumping dan Perjanjian Subsidi. Namun kedua penelitian ini belum mengukur seberapa besar dampak ekonomi terutama yang terkait dengan ekspor coated paper yang ditimbulkan dari putusan tersebut.

Bown (2005) melakukan studi investigasi untuk menyelidiki secara empiris faktor-faktor penentu keputusan 
anggota WTO tentang apakah akan menentang upaya trade remedy serta dampaknya. Dari hasil penelitian tersebut ditemukan fakta bahwa dalam beberapa kasus, trade remedy yang ditentang WTO menyebabkan suatu negara justru melakukan tindakan antidumping sendiri. Dalam beberapa kasus juga ditemui bahwa industri asing yang terkena dampak negatif akan melakukan penyelidikan sendiri tanpa melibatkan WTO. Atau dengan kata lain calon penggugat akan menghindari litigasi WTO demi mengejar tindakan antidumping sendiri.

Susila \& Saputri (2018) menyebutkan bahwa pengenaan trade remedy pada produk ekspor Indonesia akan berdampak negatif pada kinerja ekspor, pertumbuhan ekonomi, maupun lapangan kerja. Dengan demikian tindakan paling logis bagi Indonesia adalah memenangkan kasus tersebut. Penelitian tersebut menyarankan dua hal. Pertama, Indonesia harus memiliki atau membayar ahli-ahli hukum perdagangan internasional yang mumpuni, namun karena tarif ahli hukum perdagangan internasional cukup mahal, maka Indonesia harus menyediakan dana yang memadai. Kedua, Indonesia harus memperkuat diri dalam hal substansi khususnya dari sisi hukum, dimana industri yang memproduksi tidak melakukan dumping untuk kasus dumping atau pemerintah tidak melakukan subsidi untuk kasus subsidi. Namun dari penelitian tersebut juga menyatakan bahwa baik secara konsep maupun metode, penentuan tindakan tersebut masih tidak solid dan cenderung multitafsir.

Zhu, dkk (2008) melakukan penelitian untuk memprediksi efek jangka panjang dari dampak kebijakan CVD oleh Amerika Serikat terhadap impor coated free sheet paper dari Tiongkok, Korea, dan Indonesia. Dari hasil simulasi dengan menggunakan model Global Forest Product Models (GFPM) bahwa CVD memiliki efek signifikan pada negara-negara yang terlibat dalam perdagangan. Produksi kertas di Tiongkok, Indonesia, dan Korea akan menurun. Neraca perdagangan kertas akan memburuk di Korea dan Indonesia.

Dari hasil penelitian ini juga diketahui bahwa pendapatan produsen dari komoditas tersebut di Amerika Serikat saat bea impor dibebankan pada negara eksportir tidak banyak memberikan kompensasi atau meningkatkan daya saing produk yang diproduksi Amerika Serikat di pasar domestik. Faktanya pada 20 November 
2007, United States International Trade Commission (ITC) menetapkan bahwa coated free sheet paper yang diimpor dari Tiongkok, Indonesia, dan Korea tidak merugikan produsen komoditas tersebut di Amerika Serikat sehingga bea antidumping dan CVD ditiadakan. Penelitian ini juga menyarankan agar industri Amerika Serikat perlu melakukan diferensiasi produk tidak hanya dalam bentuk, namun juga kualitas untuk menjadi lebih kompetitif, dibanding mencari perlindungan dengan memberikan tarif yang lebih tinggi.

Dalam menganalisis dampak suatu kebijakan serta mengetahui besarnya dampak yang diberikan dapat menggunakan analisis intervensi. Pada umumnya pengaruh suatu kebijakan terhadap variabel respon diukur melalui dummy variable.

Gujarati, dkk (2012) menyebutkan bahwa variabel dependen seringkali dipengaruhi tidak hanya oleh variabel skala rasio, tetapi juga oleh variabel yang -secara esensial- kualitatif, seperti kondisi politik, letak geografis, termasuk di dalamnya kebijakan yang diberlakukan dalam ekonomi. Dalam hubungan kausalitas, variabel tersebut menunjukkan ada atau tidaknya suatu "kualitas" atau suatu atribut. Variabel kualitatif ini dapat dilibatkan sebagai salah satu variabel bebas dengan cara melakukan kuantifikasi terhadap atribut tersebut dengan membangun variabel buatan yang bernilai 1 atau 0 . Nilai 1 menandakan adanya atribut tersebut, dan nilai 0 menandakan tidak adanya atribut tersebut. Variabel yang mengasumsikan nilai 0 dan 1 disebut variabel dummy.

Meskipun mudah untuk mengikutsertakan variabel yang menunjukkan ada tidaknya suatu kebijakan ke dalam pemodelan kausalitas dalam bentuk dummy variable, namun Gujarati, dkk (2012) menekankan kelemahan penggunaan variabel tersebut, diantaranya jika variabel kualitatif memiliki lebih dari satu kategori maka peneliti tidak dapat memasukkan seluruh variabel dummy ke dalam model regresi karena akan menyebabkan adanya permasalahan kolinearitas sempurna, yaitu hubungan linier yang sempurna/pasti di antara variabel. Pada kasus seperti ini akan menyebabkan estimasi koefisien regresi tidak dapat diperoleh. Dengan demikian apabila variabel kualitatif memiliki kategori sebanyak $m$, maka peneliti hanya dapat menggunakan variabel dummy sebanyak $m-1$. Selain itu pada variabel kualitatif yang memiliki lebih 
dari satu kategori, maka pilihan kategori yang akan digunakan sebagai kategori acuan sepenuhnya diserahkan kepada peneliti. Namun perbedaan pemilihan kategori acuan akan menyebabkan perbedaan kesimpulan dari penelitian.

Selain itu Neter, dkk (1989) menjelaskan bahwa dalam pemodelan regresi, ada/tidaknya suatu kebijakan dikategorikan ke dalam variabel kualitatif dan diberikan pengkodean 0 dan 1. Pengamatan yang diberikan kode 0 akan menyebabkan koefisien variabel tersebut tidak berperan dalam memengaruhi variabel respon, sedangkan ketika dummy diberikan kode 1 maka koefisiennya berperan untuk mengubah intersep model regresi. Interpretasi dari koefisien yang dihasilkan juga sangat bergantung dari variabel kuantitatif yang ada di dalam model. Dalam penelitian ini, kebijakan trade remedy dapat digunakan pada model kausalitas dengan menggunakan variabel dummy, dimana kode 0 merupakan periode dimana kebijakan trade remedy belum diberlakukan, dan kode 1 merupakan periode dimana kebijakan trade remedy telah diberlakukan. Namun, penggunaan dummy variable di dalam pemodelan regresi tidak dapat mengukur secara kuantitatif besarnya dampak yang ditimbulkan oleh suatu kebijakan.

Dengan demikian analisis intervensi lebih baik digunakan dibandingkan analisis dengan dummy variable. Berikut adalah beberapa penelitian yang menerapkan metode tersebut.

Sari, dkk (2016), melakukan penelitian menggunakan analisis intervensi yang bertujuan untuk menentukan dampak kebijakan deviden terhadap PT. Fast Food Indonesia Tbk. Hasil penelitian menyimpulkan bahwa kebijakan terkait deviden menyebabkan penurunan harga saham secara signifikan namun tidak memiliki dampak dalam jangka panjang.

Chung \& Chan (2009), menggunakan metode ini untuk menganalisis dampak krisis keuangan terhadap industri manufaktur di Tiongkok. Hasil penelitian menunjukkan bahwa dampak intervensi karena krisis keuangan global yang meluas ke Tiongkok memiliki dampak negatif terhadap industri manufaktur Tiongkok, dimana intervensi tersebut memberikan dampak sebesar 27,74\%. Intervensi mulai dirasakan dengan ditandai adanya penurunan nilai output industri manufaktur dan penurunan terus berlanjut pada bulan berikutnya. 
Unnikrishnan \& Suresh (2016) menggunakan metode ini untuk menjelaskan pengaruh pemberlakuan kebijakan bea masuk sebesar $10 \%$ untuk emas oleh pemerintah India terhadap harga domestik. Hasil penelitian menunjukkan bahwa terjadi penurunan harga emas domestik yang signifikan sebesar $56 \%$.

Berdasarkan permasalahan yang ada maka penelitian ini bertujuan untuk menganalisis pengaruh kebijakan trade remedy terhadap ekspor coated paper Indonesia ke Amerika Serikat. Sebagai salah satu negara utama tujuan ekspor coated paper Indonesia, penurunan ekspor ke Amerika Serikat diindikasikan menjadi yang terbesar dibandingkan dengan negara tujuan utama ekspor lainnya. Selain itu, penelitian ini juga ingin mengetahui kapan dampak trade remedy mulai berpengaruh dan mengukur seberapa besar dampak kebijakan trade remedy terhadap ekspor coated paper Indonesia ke Amerika Serikat.

Penelitian ini penting untuk dilakukan karena trade remedy yang dialami produk coated paper Indonesia di Amerika Serikat dikhawatirkan berpotensi menjadi preseden dimana negara-negara tujuan utama ekspor lainnya seperti Tiongkok, Uni Eropa,
India, Australia, dan Korea Selatan akan menggunakan cara yang sama untuk menghambat ekspor coated paper Indonesia. Dampak negatif terhadap kinerja ekspor ini juga dapat berlanjut ke indikator ekonomi lainnya seperti perlambatan pertumbuhan industri kertas.

\section{METODE}

Metode analisis yang digunakan adalah model ARIMA Intervensi. Data time series yang dipengaruhi oleh beberapa kejadian eksternal misalnya penerapan suatu kebijakan yang disebut intervensi akan menyebabkan perubahan pola data pada satu waktu tertentu (Wei, 2006). Sesuai dengan tujuan penelitian ini yaitu menganalisis pengaruh kebijakan trade remedy terhadap ekspor coated paper Indonesia ke Amerika Serikat, maka analisis intervensi tepat untuk digunakan karena dapat mengukur seberapa besar dan lamanya efek intervensi yang terjadi pada waktu tertentu. Hubungan tersebut dapat dituliskan dalam bentuk (Wei, 2006):

$Y_{t}=\theta_{0}+\frac{\omega_{S}(B) B^{b}}{\delta_{r}(B)} I_{t}+N_{t}$

dengan :

$Y_{t}$ : Volume ekspor coated paper $(\mathrm{kg})$ Indonesia ke Amerika Serikat pada waktu ke-t 
$\theta_{0}:$ Konstanta

It : Variabel Intervensi pada waktu ke-t, bernilai 0 atau 1 yang menunjukkan ada tidaknya intervensi pada waktu ke-t

$\omega_{s}: \omega_{0}-\omega_{1} B-\cdots-\omega_{s} B^{s}$

$\delta_{r}: 1-\delta_{r} \mathrm{~B}-\ldots-\delta_{r} B^{r}$

$N_{t}$ : Model ARIMA tanpa adanya intervensi

$$
N_{t}=\frac{\theta_{q} B}{\emptyset_{p}(B)} \varepsilon_{t}
$$

dengan:

$\theta_{q}$ : Parameter moving average ke-q

$\emptyset_{p}$ : Parameter autoregressive ke- $p$

$B$ :Operator Backshift

$\varepsilon_{t}:$ error term

Dalam persamaan (1) karena intervensi yang digunakan adalah berupa kebijakan (trade remedy), maka fungsi yang digunakan dalam analisis intervensi ini adalah fungsi step. Secara matematik fungsi step dimodelkan sebagai berikut:

$$
I_{t}=S_{t}^{T}=\left\{\begin{array}{l}
0, t<T \\
1, t \geq T
\end{array}\right.
$$

dengan $\mathrm{T}$ adalah periode dimulainya intervensi. Dengan demikian model intervensi pada penelitian ini adalah:

$Y_{t}=\theta_{0}+\frac{\omega_{s}(B) B^{b}}{\delta_{r}(B)} S_{t}^{T}+N_{t}$

Berikut ini adalah tahapan pembentukan model ARIMA intervensi:
1. Pengelompokkan data berdasarkan waktu terjadinya intervensi

a. Data I merupakan data sebelum adanya intervensi (kebijakan pengenaan BMAD dan CVD oleh Amerika Serikat terhadap ekspor kertas Indonesia). Dimulai dari Januari 2006 sampai Desember 2009 $(\mathrm{t}=1,2, \ldots 48)$.

b. Data II merupakan data saat terjadinya intervensi sampai akhir periode penelitian yaitu, Januari 2010 sampai Desember $2018(\mathrm{t}=49, \ldots 156)$.

2. Membangun model ARIMA BoxJenkins sebelum intervensi menggunakan data I

3. Melakukan uji diagnostik pada model ARIMA terbaik yang telah terbentuk dan uji asumsi normalitas dan independensi error

4. Melakukan peramalan dengan menggunakan model ARIMA sebelum intervensi yang telah terbentuk untuk periode data II

5. Menghitung nilai residual $\left(Y_{t}^{*}\right)$ untuk data II

6. Membentuk plot residual $\left(Y_{t}^{*}\right)$ dari data II

7. Menentukan ordo $b, s$, dan $r$ dengan hasil ploting residual dengan batas \pm 2 standar deviasi. Dimana nilai 
standar deviasi diperoleh dari $\sigma=$ $\sqrt{\frac{\sum\left(Y_{t}^{*}-\overline{Y_{t}^{*}}\right)^{2}}{n}}$

8. Melakukan estimasi parameter dan uji signifikansi untuk ordo $b, s$, dan $r$ yang telah terpilih pada ARIMA intervensi (b adalah waktu pertama kali dampak intervensi dirasakan; $s$ adalah waktu dampak intervensi berfluktuasi; dan $r$ adalah pola dari dampak intervensi

9. Melakukan uji diagnostik pada model ARIMA intervensi yang telah terbentuk, apakah residualnya sudah berdistribusi normal dan white noise.

10. Apabila langkah 9 belum terpenuhi, ulangi langkah 8. Sebaliknya, jika langkah 9 terpenuhi, maka model intervensi sudah terbentuk dengan pemilihan model terbaik.

Data yang digunakan adalah data sekunder yang diperoleh dari Kementerian Perdagangan Republik Indonesia yaitu, data bulanan volume ekspor coated paper Indonesia ke Amerika Serikat dalam satuan kilogram dari bulan Januari 2006 sampai bulan Desember 2018.

\section{HASIL DAN PEMBAHASAN}

Amerika serikat merupakan salah satu pasar utama ekspor coated paper Indonesia. Gambaran volume ekspor coated paper Indonesia ke Amerika Serikat disajikan pada gambar 2 . Berdasarkan gambar 2. volume ekspor coated paper Indonesia ke Amerika Serikat terbesar terjadi pada September 2007 yaitu sebesar 8.342 ton. Sedangkan, volume ekspor terendah terjadi pada Februari 2010, yaitu sebesar 136,4 ton. Penurunan ini diindikasikan terkait dengan penurunan harga kertas di pasar global. Kemudian pada Oktober 2010 terjadi kenaikan yang signifikan pada volume ekspor coated paper ke Amerika Serikat.

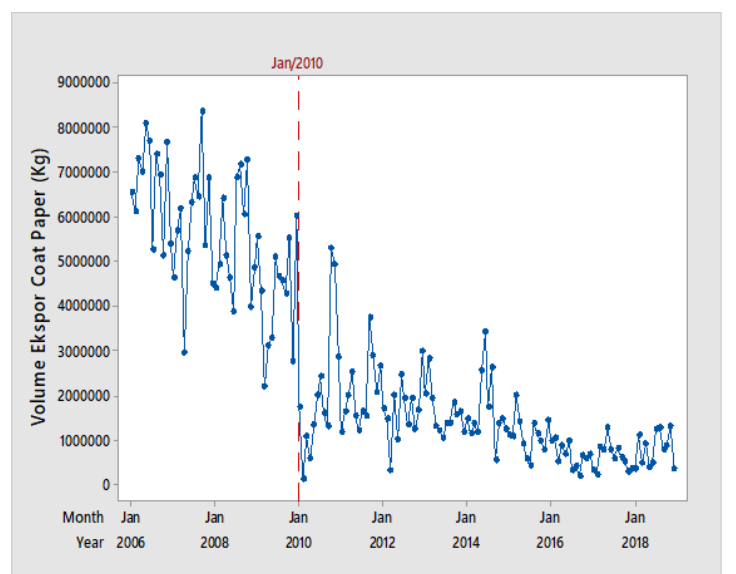

Gambar 2. Plot Time Series Volume Ekspor Coated Paper Bulanan Indonesia ke Amerika Serikat, 2006-2018

Sumber: Kementerian Perdagangan RI (2020)

Hal ini dikarenakan adanya peningkatan kapasitas produksi global secara signifikan, dimana sekitar setengah dari produksi global tersebut, tujuannya ke pasar Amerika Serikat dan Uni Eropa sehingga diindikasikan terjadi persaingan pasar Indonesia dengan 
eksportir lainnya (Kementerian Perdagangan, 2015). Menurut Kementerian Perdagangan (2018), produk ekspor coated paper Indonesia dikenakan BMAD dan CVD oleh Amerika Serikat pada Januari 2010. Coated paper dikenakan CVD sebesar $17,94 \%$ dan BMAD sebesar 20,13\%.

Gambar 2 membagi data menjadi dua series sesuai waktu intervensi, dimana series pertama merupakan data sebelum terjadinya intervensi, sementara series kedua merupakan data setelah terjadinya intervensi. Sebelum adanya intervensi berupa pengenaan CVD dan BMAD pada bulan Januari 2006 sampai Desember 2009, ekspor coated paper memiliki volume ekspor yang lebih besar dibandingkan dengan volume ekspor setelah adanya intervensi namun memiliki kecenderungan yang menurun. Ketika ekspor coated paper Indonesia dikenakan CVD dan BMAD pada Januari 2010 oleh Amerika Serikat, volume ekspor coated paper Indonesia ke Amerika Serikat turun secara drastis. Terjadi penurunan ekspor coated paper sebesar $21,2 \%$ sepanjang tahun 2010 hingga 2017. Hal ini diindikasikan sebagai dampak dari pengenaan kebijakan tersebut.
Proses Pembentukan Model ARIMA Intervensi Trade Remedy

\section{a. Membagi Data berdasarkan Waktu Intervensi}

Langkah awal dalam membangun model ARIMA intervensi adalah mengelompokkan data berdasarkan waktu intervensinya. Pembagian data berdasarkan waktu intervensi bisa dilihat pada Gambar 2. Periode waktu dalam penelitian ini dibagi dua bagian. Periode pertama merupakan kelompok data sebelum adanya intervensi trade remedy yaitu, 2006 hingga 2009. Periode kedua merupakan kelompok data pada periode adanya intervensi trade remedy berupa CVD dan BMAD oleh Amerika Serikat, yaitu 2010 hingga 2018. Periode pertama digunakan untuk membangun model ARIMA sebelum intervensi. Sementara bagian periode kedua digunakan untuk membentuk model ARIMA intervensi yang merupakan lanjutan dari model ARIMA sebelum intervensi dan final model ARIMA intervensi pada penelitian ini.

\section{b. Membangun Model ARIMA Sebelum Intervensi}

Pembentukan model ARIMA dari data yang tidak mengandung intervensi merupakan langkah awal untuk membentuk model intevensi. Model ARIMA sebelum intervensi merupakan 
pembentukan model ARIMA klasik atau dinamakan model ARIMA Box-Jenkins. Untuk membentuk model Box-Jenkins diperlukan empat tahapan yaitu, identifikasi model tentatif, estimasi parameter model, evaluasi model, dan peramalan.

Sebelum memasuki tahapan identifikasi model, data yang akan digunakan harus memenuhi asumsi stasioneritas, baik stasioner di rata-rata maupun stasioner di varians. Apabila data tidak stasioner dalam varians, maka data dapat ditransformasi dengan transformasi Box-Cox (Enders, 2004). Sementara, apabila data tidak stasioner pada rata-rata, maka dapat dilakukan differencing pada data.

Pengecekan stasioneritas di varians atau ragam dapat dilihat dengan bantuan metode transformasi Box-Cox. Data dapat dikatakan stasioner pada varians apabila nilai rounded-value atau lambda $(\lambda)$ bernilai 1 atau lebih dari satu (Aritonang, 2009). Lambda ( $\lambda$ ) adalah sebuah parameter tunggal yang akan diduga. Berdasarkan hasil pengolahan data, menunjukkan bahwa data belum stasioner pada varians. Oleh sebab itu dilakukan transformasi data, berupa transformasi akar $\left(\sqrt{Y_{t}}\right)$. Setelah dilakukan transfomasi, maka diperoleh nilai rounded-value 2,00 seperti yang terlihat pada Gambar 3.

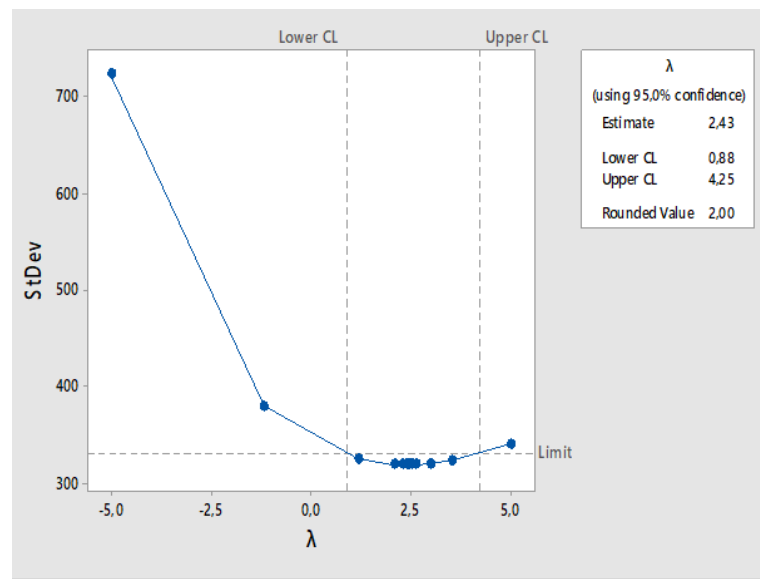

Gambar 3. Hasil Transformasi Box-Cox Sumber: Hasil Pengolahan

Oleh sebab itu, dapat disimpulkan data sudah stasioner pada varians. Langkah selanjutnya adalah pengujian asumsi stasioneritas pada rata-rata dengan menggunakan Augmented Dickey-Fuller (ADF) test. Berdasarkan hasil pengolahan data, diperoleh $p$ value sebesar 0,0006 Dengan demikian dapat disimpulkan bahwa dengan tingkat signifikansi $5 \%$ data tidak memiliki akar unit (data stasioner pada tingkat level).

Setelah asumsi stasioneritas terpenuhi, selanjutnya dilakukan identifikasi model ARIMA dengan menggunakan plot ACF dan PACF. Dari plot ACF dan PACF dapat dilihat berbagai kombinasi ordo AR dan MA untuk membentuk model tentatif. Model ARIMA yang memenuhi syarat 
signifikansi parameter adalah ARIMA $(1,0,0)$ dan ARIMA $(2,0,0)$.

Tabel 1. Model ARIMA Klasik dengan Nilai AIC dan SBC

\begin{tabular}{ccc}
\hline ARIMA & AIC & SBC \\
\hline$(1,0,0)$ & 687,225 & 690,967 \\
$(2,0,0)$ & 689,087 & 692,829
\end{tabular}

Sumber: Hasil Pengolahan

Dari dua model yang diperoleh, dipilih model dengan nilai AIC dan SBC terkecil, yakni model ARIMA $(1,0,0)$. Oleh sebab itu, model ARIMA $(1,0,0)$ diduga sebagai model terbaik dalam penelitian ini. Langkah selanjutnya yang dilakukan adalah estimasi parameter dan evaluasi model berupa pengujian independensi error dan normalitas error pada model ARIMA $(1,0,0)$.

Tabel 2. Hasil Estimasi dan Uji Signifikansi Parameter

\begin{tabular}{cc}
\hline Estimasi & $P$-value \\
\hline$\mu^{\prime}=2341,0$ & $<0,0001$ \\
$\varnothing 1=0,37343$ & 0,0090
\end{tabular}

Sumber: Hasil Pengolahan

Tabel 2, menunjukkan bahwa seluruh estimasi parameter dari model ARIMA $(1,0,0)$ memiliki nilai $p$-value kurang dari alfa $(\alpha=0,05)$. Artinya, parameter dari model ARIMA $(1,0,0)$ signifikan.
Tabel 3. Hasil uji independensi

\begin{tabular}{ccc}
\hline Lag & $\begin{array}{c}\text { Statistik } \\
\text { Ljung-Box }\end{array}$ & $P$-value \\
\hline 6 & 7,27 & 0,2015 \\
12 & 10,85 & 0,4563 \\
18 & 14,3 & 0,6458 \\
24 & 24,79 & 0,3613 \\
\hline Sumber: Hasil Pengolahan &
\end{tabular}

Berdasarkan Tabel 3, untuk uji independensi error diperoleh hasil bahwa nilai $p$-value untuk seluruh lag lebih dari alfa $(\alpha=0,05)$. Sehingga, dengan tingkat signifikansi $5 \%$, dapat disimpulkan bahwa model ARIMA $(1,0,0)$ memenuhi asumsi independensi error. Sementara dari hasil uji normalitas diperoleh $p$-value sebesar 0,06. Dengan demikian dapat disimpulkan bahwa model ARIMA $(1,0,0)$ memenuhi asumsi normalitas error.

Secara matematis, model ARIMA $(1,0,0)$ yang telah memenuhi asumsi dapat dinyatakan dalam bentuk:

$\widetilde{\boldsymbol{Y}}_{\mathrm{t}}=2341,0+0,37343 \widetilde{\boldsymbol{Y}}_{\mathrm{t}-1}$

dimana $\tilde{Y}_{t}=\sqrt{Y_{t}}$

Langkah berikutnya adalah peramalan dengan model ARIMA $(1,0,0)$ untuk data setelah intervensi, yaitu data volume ekspor coated paper Indonesia ke Amerika Serikat pada bulan Januari 2010 sampai dengan bulan Desember 2018. Peramalan ini dilakukan untuk mencari nilai residual, 
dimana nilai residual ini diperoleh dari selisih antara data aktual dari bulan Januari 2010 sampai bulan Desember 2018 dengan data peramalan yang telah diperoleh dari model ARIMA sebelum intervensi.

\section{c. Membangun Model ARIMA Intervensi}

Intervensi dalam penelitian ini adalah kebijakan yang dikeluarkan oleh Amerika Serikat pada Indonesia yaitu, kebijakan trade remedy berupa pengenaan CVD dan BMAD terhadap ekspor produk coated paper pada tanggal 1 Januari 2010. Berdasarkan laporan kajian Pusat Kebijakan Perdagangan Luar Negeri, Kementerian Perdagangan, Amerika Serikat mengenakan BMAD sebesar 20,13\% dan CVD sebesar $17,94 \%$ untuk produk ekspor coated paper Indonesia.

Setelah diperoleh model ARIMA sebelum intervensi dengan data dalam bentuk akar dari volume ekspor coated paper Indonesia ke Amerika Serikat, langkah berikutnya adalah membentuk model ARIMA intervensi. Identifikasi model untuk ARIMA intervensi dilakukan dengan melihat pola residual saat intervensi dan sesudah terjadinya intervensi. Penentuan garis signifikansi pada plot residual respon intervensi diperoleh dari perhitungan dua kali nilai standar deviasi $(\sigma)$ residual model ARIMA sebelum intervensi. Setelah memperoleh plot residual respon intervensi, langkah selanjutnya yaitu menentukan ordo $b, s$, dan $r$ dengan melihat dari hasil peramalan yang keluar dari batas $\pm 2 \sigma$. Nilai $\sigma$ diperoleh dari hasil pengolahan data pada output ketika uji kenormalan residual. Nilai standar deviasi residual model ARIMA sebelum intervensi pada penelitian adalah 301,41051 sehingga batasnya adalah $\pm 602,821$.

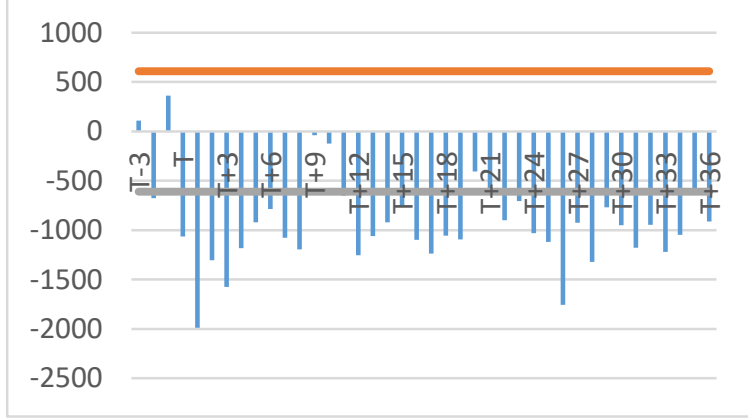

\section{Gambar 4. Plot Residual Intervensi}

Sumber: Hasil Pengolahan

Berdasarkan plot residual pada Gambar 4, secara keseluruhan nilai-nilai residual respon intervensi bernilai negatif. Hal ini menunjukkan jika kebijakan pengenaan CVD dan BMAD mengakibatkan penurunan volume ekspor coated paper Indonesia ke Amerika Serikat. Dalam menentukan ordo $b, s$, dan $r$ dilakukan proses trial and error untuk mencari ordo terbaik sebagai ordo pembentuk model intervensi. Ordo $b$ merupakan ordo yang 
menunjukkan waktu pertama kali suatu dampak intervensi signifikan dirasakan.

Ordo $s$ menunjukkan dampak intervensi mengalami fluktuasi yang signifikan. Dan ordo $r$ menunjukkan pola dari suatu dampak intervensi.

Berdasarkan Gambar 4, residual pertama kali melewati batas $2 \sigma$ $(602,821)$ pada periode ke 0 (T) atau saat terjadinya intervensi, sehingga dapat diduga bahwa ordo $b$ adalah $b=0$. Setelah dilakukan proses trial and error diperoleh hasil bahwa ordo $b=0$ menunjukkan hasil yang signifikan. Selanjutnya, berdasarkan plot residual respon intervensi, diperoleh model intervensi dengan ordo $b=0, s=(9$ dan 26), dan $r=0$. Artinya, dampak intervensi pertama kali dirasakan saat itu juga sehingga tidak ada waktu tunggu (T) yaitu, pada Januari 2010. Dan ordo $s$ bernilai 9 dan 26, hal ini menunjukkan residual berfluktuasi pada $T+9$ dan $T+26$ setelah ordo $b$. sementara ordo $r$ bernilai 0 , artinya nilai-nilai residual yang menggambarkan dampak intervensi ini tidak memiliki pola atau memiliki pola acak (random).

Setelah diperoleh model ARIMA intervensi dengan ordo-ordo yang telah ditentukan, maka langkah selanjutnya adalah estimasi parameter, uji independensi error dan uji normalitas error pada model intervensi.

Tabel 4. Hasil Estimasi dan Signifikansi Parameter

\begin{tabular}{cc}
\hline Estimasi & $P$-value \\
\hline$\mu^{\prime}=2209,5$ & $<0,0001$ \\
$\varphi=0,48391$ & $<0,0001$ \\
$\omega_{0}=-1197,4$ & $<0,0001$ \\
$\omega_{1}=-571,44593$ & 0,0029 \\
$\omega_{2}=554,97606$ & $<0,0001$ \\
\hline
\end{tabular}

Sumber: Hasil pengolahan

Berdasarkan Tabel 4, estimasi parameter telah memenuhi syarat signifikansi karena nilai $p$-value kurang dari 0,05 .

Tabel 5. Hasil Uji independensi

\begin{tabular}{|c|c|c|}
\hline Lag & $\begin{array}{c}\text { Statistik } \\
\text { Ljung- Box }\end{array}$ & $P$-value \\
\hline 6 & 7,79 & 0,1683 \\
\hline 12 & 14,18 & 0,2233 \\
\hline 18 & 19,11 & 0,3225 \\
\hline 24 & 25,82 & 0,3094 \\
\hline
\end{tabular}

Sumber: Hasil pengolahan

Berdasarkan Tabel 5 nilai $p$-value pada seluruh lag lebih dari 0,05. Sehingga dapat disimpulkan bahwa pada tingkat signifikansi $5 \%$ model intervensi telah memenuhi asumsi error bersifat random (white noise). Selain itu berdasarkan uji normalitas diperoleh $p$ value $=0,4433$ dan disimpulkan bahwa error berdistribusi normal. Dengan demikian seluruh asumsi yang diperlukan telah terpenuhi. 
Secara matematis model ARIMA intervensi $(1,0,0)$ dengan ordo $b=0, s=9$ dan 26, $r=0$ persamaannya dapat dituliskan sebagai berikut:

$$
\begin{aligned}
\tilde{Y}_{t}= & 2209,5-1197,4 S_{t}+571,44593 S_{t-9} \\
& -554,97606 S_{t-26}+0,48391 \tilde{Y}_{t-1} \ldots(3)
\end{aligned}
$$

Dimana $\tilde{Y}_{t}=\sqrt{Y_{t}}$

Parameter ordo $b$ yang bernilai negatif menunjukkan bahwa, dampak awal yang terjadi setelah penetapan kebijakan pengenaan CVD dan BMAD oleh Amerika Serikat terhadap ekspor coated paper Indonesia pada tahun 2010 adalah penurunan volume ekspor coated paper Indonesia. Ordo $b$ pada intervensi ini bernilai 0, artinya dampak dari kebijakan pengenaan CVD dan BMAD oleh Amerika Serikat terhadap produk ekspor coated paper Indonesia langsung dirasakan pada waktu itu juga yaitu pada bulan Januari 2010. Tidak adanya jeda atau delay dari dampak trade remedy menunjukkan bahwa kebijakan ini berpengaruh signifikan terhadap ekspor coated paper Indonesia ke Amerika Serikat, yaitu terjadinya penurunan ekspor coated paper secara drastis.

\section{d. Dampak Intervensi Kebijakan} Trade Remedies oleh Amerika Serikat terhadap Ekspor Coated Paper Indonesia

Langkah awal dalam perhitungan besarnya dampak intervensi adalah melakukan forecasting menggunakan model ARIMA yang telah diperoleh dalam proses sebelumnya. Dikarenakan data yang digunakan dalam penelitian ini adalah data transformasi dalam bentuk akar $\mathrm{Y}_{\mathrm{t}}\left(\sqrt{Y_{t}}\right)$, maka diperlukan invert data. Menurut Maspupah (2013), invert data perlu dilakukan apabila data yang digunakan dalam suatu penelitian adalah data transformasi. Dalam penelitian ini invert dilakukan dengan menguadratkan tiap data. Setelah didapatkan data ramalan, kemudian dilakukan invert, langkah selanjutnya adalah menghitung selisih antara nilai forecast dari model intervensi dengan model ketika tidak ada intervensi (Lee, M.H, et al, 2010).

Dampak dari pengenaan CVD dan BMAD oleh Amerika Serikat terhadap ekspor coated paper Indonesia mulai dirasakan pada bulan Januari 2010. 
Artinya, pengenaan kebijakan tersebut langsung dirasakan pada periode itu juga, saat kebijakan ditetapkan. Tidak membutuhkan waktu yang lama bagi intervensi tersebut untuk memiliki dampak atau pengaruh yang signifikan terhadap volume ekspor coated paper Indonesia.

Tabel 6. Besar Dampak Intervensi

\begin{tabular}{ccc}
\hline Waktu & Periode & Persentase \\
\hline $\mathrm{T}$ & Januari 2010 & $-77,55 \%$ ^ \\
$\mathrm{T}+1$ & Februari 2010 & $-75,74 \%$ \\
$\mathrm{~T}+2$ & Maret 2010 & $-91,07 \%$ \\
$\mathrm{~T}+3$ & April 2010 & $-80,79 \%$ \\
$\mathrm{~T}+4$ & Mei 2010 & $-85,41 \%$ \\
$\mathrm{~T}+5$ & Juni 2010 & $-78,62 \%$ \\
$\mathrm{~T}+6$ & Juli 2010 & $-73,33 \%$ \\
$\mathrm{~T}+7$ & Agustus 2010 & $-70,29 \%$ \\
$\mathrm{~T}+8$ & September 2010 & $-76,49 \%$ \\
$\mathrm{~T}+9$ & Oktober 2010 & $-50,36 \%$ \\
$\mathrm{~T}+10$ & November 2010 & $-31,96 \%$ \\
$\ldots$ & $\ldots$ & $\ldots$ \\
$\mathrm{T}+107$ & Desember 2018 & $-78,32 \%$ \\
\hline
\end{tabular}

Sumber: Hasil Pengolahan

Ket: ^Nilai diperoleh dari rasio antara selisih nilai forecast model intervensi dan forecast model pra intervensi dengan forecast model pra intervensi. Untuk periode Januari diperoleh (-4.398.698,963/ $5.672 .018,867)^{*} 100 \%=-77,55$

Berdasarkan Tabel 6, dampak dari pengenaan kebijakan CVD dan BMAD tersebut menyebabkan penurunan volume ekspor coated paper Indonesia ke Amerika Serikat. Terlihat bahwa persentase penurunan volume ekspor coated paper Indonesia ke Amerika
Serikat cukup besar sejak kebijakan tersebut diberlakukan.

Dampak intervensi pertama kali dirasakan pada bulan Januari 2010, dimana terjadi penurunan volume ekspor coated paper Indonesia ke Amerika Serikat sebesar $77,55 \%$ atau sekitar 4.400 ton. Pada bulan berikutnya, Februari 2010, dampak intervensi penurunan volume ekspor coated paper Indonesia mengalami penurunan menjadi $75,7 \%$ dibanding periode sebelumnya, sementara bulan Maret 2010 mengalami peningkatan kembali menjadi $91,1 \%$ (5.015 ton). Penurunan pada Maret 2010 merupakan penurunan yang terbesar ketika trade remedy diberlakukan selama periode penelitian. Kemudian, pada bulan Oktober 2010 dampak intervensi berfluktuasi signifikan yang menyebabkan penurunan dampak intervensi menjadi 2759,949 ton atau sekitar 50,4\%. Penurunan yang terus menerus ini salah satunya juga didukung dengan kondisi perekonomian Amerika Serikat di tahun 2010 yang masih terdampak krisis global tahun 2008. Dalam proyeksi IMF (2010), perekonomian Amerika Serikat masih mengalami pukulan terbesar dengan pertumbuhan minus $2,8 \%$ tahun 2009 dan nol persen di 2009. Dalam proyeksi 
sebelumnya, Amerika Serikat diprediksi tumbuh $-1,2 \%$ di 2009 dan $-1,6 \%$ di 2010 (Krugman \& Wells, 2010). Dampak intervensi ini terus mengakibatkan penurunan terhadap ekspor kertas pada bulan selanjutnya dan secara umum dampak penurunan ini berfluktuasi dan cenderung mengalami peningkatan. Hal ini menunjukkan bahwa, intervensi kebijakan CVD dan BMAD terhadap ekspor coated paper Indonesia oleh Amerika Serikat signifikan menurunkan volume ekspor coated paper Indonesia dan dampak penurunan volume ekspor coated paper dapat dikatakan permanen hingga akhir periode penelitian.

Hal ini sejalan dengan penelitian yang dilakukan oleh Safitri (2014), yang menyebutkan bahwa Amerika Serikat merupakan negara importir utama ekspor kertas Indonesia pada tahun 2000-2012. Ekspor kertas Indonesia memiliki daya saing yang kuat di pasar Amerika Serikat, selain itu kertas Indonesia juga memiliki keunggulan komparatif di pasar Amerika Serikat. Selama periode tahun 2000 sampai 2012 ekspor kertas Indonesia mengalami peningkatan dari tahun ke tahun. Namun pada tahun 2010, sempat terjadi penurunan laju perkembangan ekspor kertas Indonesia ke Amerika
Serikat sebesar 1,128\%. Dan sepanjang tahun 2013 hingga 2017 laju pertumbuhan ekspor kertas Indonesia ke Amerika mengalami penurunan sebesar 6,26\% (Indonesia Eximbank Institute, 2019).

Hal ini juga sejalan dengan laporan dari Indonesia Eximbank Institute (2019), yang melaporkan bahwa, pertumbuhan produk ekspor coated paper mengalami penurunan sebesar 10,91\% sepanjang tahun 2013 hingga 2017. Selain itu, nilai ekspor coated paper juga terus mengalami penurunan tiap tahunnya, dimana pada tahun 2012 nilai ekspor coated paper sebesar USD 602 juta, kemudian pada tahun 2017 terjadi penurunan menjadi USD 345 juta.

Berdasarkan penelitian yang dilakukan oleh Susila \& Saputri (2018), Indonesia mengalami pengenaan kebijakan trade remedy pada tahun 2010. Penelitian ini menemukan bahwa tindakan trade remedy yang dihadapi produk ekspor kertas Indonesia khususnya coated paper mengalami penurunan pangsa pasar sebesar $2,6 \%$ ke Amerika Serikat dan secara keseluruhan akan mengalami penurunan ekspor kertas ke dunia sebesar $27,97 \%$. Selain itu, tindakan trade remedy yang dihadapi produk 
ekspor Indonesia diperkirakan akan terus berlanjut. Penurunan kinerja ekspor akan merambat ke indikator ekonomi lainnya, seperti perlambatan pertumbuhan industri.

Hal ini juga sejalan dengan data perdagangan Indonesia yang memperlihatkan bahwa ekspor coated paper Indonesia ke dunia terus mengalami penurunan dari tahun ke tahun. Hal ini disebabkan karena pasar Amerika Serikat merupakan importir utama ekspor coated paper Indonesia sehingga memiliki pengaruh yang kuat terhadap ekspor coated paper Indonesia. Ketika, ekspor coated paper dikenakan kebijakan trade remedy, maka kondisi ekspor coated paper Indonesia mengalami guncangan ke Amerika Serikat. Selain itu, ekspor coated paper Indonesia belum mampu menemukan pasar baru sebesar Amerika Serikat. Sehingga, volume ekspor coated paper Indonesia terus mengalami penurunan.

\section{KESIMPULAN DAN REKOMENDASI KEBIJAKAN}

Berdasarkan hasil penelitian maka disimpulkan bahwa perkembangan volume ekspor produk kertas coated paper Indonesia pada Januari 2006 hingga Desember 2018 secara umum mengalami penurunan dari tahun ke tahun. Volume ekspor coated paper Indonesia ke Amerika Serikat terbesar terjadi pada September 2007 yaitu sebesar 8.342 ton. Sedangkan, volume ekspor terendah terjadi pada Februari 2010 , yaitu sebesar 136,4 ton.

Dampak awal pengenaan CVD dan BMAD pada Januari 2010 terhadap ekspor coated paper langsung dirasakan pada bulan tersebut, dimana terjadi penurunan ekspor coated paper ke Amerika Serikat sebesar 4.400 ton atau $77,55 \%$ dari sebelum adanya intervensi. Dampak intervensi ini terus mengakibatkan penurunan terhadap ekspor coated paper pada bulan selanjutnya dan secara umum dampak penurunan ini mengalami peningkatan. Hal ini menunjukkan bahwa, intervensi kebijakan CVD dan BMAD terhadap ekspor coated paper Indonesia oleh Amerika Serikat signifikan menurunkan volume ekspor coated paper Indonesia ke negara tersebut. Dan dampak kebijakan trade remedy terhadap kecenderungan penurunan ekspor coated paper Indonesia berlangsung sepanjang waktu penelitian sejak pertama kali kebijakan trade remedy diterapkan dan cenderung permanen.

Berdasarkan kesimpulan tersebut maka direkomendasikan agar pemerintah melakukan evaluasi kembali 
terkait dengan pengenaan trade remedy terhadap produk coated paper Indonesia oleh Amerika Serikat yang sekaligus menjadi salah satu pasar utama coated paper Indonesia. Merujuk pada hasil penelitian Susila \& Saputri (2018), cara yang dapat digunakan adalah dengan memperkuat bukti-bukti administratif khususnya substansi dari sisi hukum untuk membantah tuduhan yang diberikan seperti kasus dumping dan subsidi. Salah satu cara yang dapat digunakan adalah dengan memperkuat basis data perdagangan luar negeri yang terintegrasi dengan konsep Portal Satu Data Perdagangan Indonesia. Dalam portal ini, berbagai data administrasi terkait semua perusahaan yang bergerak di bidang ekspor terutama coated paper, ijin usaha dan ijin ekspor, jenis komoditas yang diperdagangkan terutama jenis kertas yang lebih detail yang diperkarakan, negara tujuan ekspor, harga jual dalam negeri dan harga ekspor, subsidi yang diberikan pemerintah, dan lain-lain terintegrasi dengan baik serta memiliki konsep yang tepat (tidak multitafsir) dan dapat diakses dengan mudah terutama oleh pihak-pihak yang berkepentingan. Terkait dengan hal ini, disarankan untuk penelitian selanjutnya dapat berfokus pada kajian yang lebih mendalam tentang mekanisme dan tata laksana dari penerapan Portal Satu Data Perdagangan Indonesia.

Selain itu evaluasi terhadap kebijakan ekspor juga perlu dilakukan. Turunnya ekspor coated paper ke Amerika Serikat dan bersifat permanen harus mulai dapat diantisipasi dengan cara mencari negara importir lain yang bersifat nontradisional. Hal ini didasarkan pada Kementerian Perdagangan (2019) dimana salah satu cara untuk kembali meningkatkan ekspor adalah dengan menggencarkan perjanjian dagang dan ekonomi dengan pasar nontradisional sebagai upaya mencari pasar baru. Perundingan dagang dan kerjasama ekonomi yang diiringi dengan peningkatan daya saing produk akan bermanfaat untuk memacu dan memperluas pangsa pasar ekspor coated paper di negara-negara nontradisional.

\section{UCAPAN TERIMAKASIH}

Penulis mengucapkan terima kasih pada Politeknik Statistika STIS atas dukungan yang telah diberikan.

\section{DAFTAR PUSTAKA}

Aritonang, R. (2009). Peramalan Bisnis. Jakarta: Ghalia

Beaulieu, E \& Prévost, D. (2020). Subsidy Determination, Benchmarks and Adverse Inferences: Assessing 'benefit' in US - Coated Paper 
(Indonesia). World Trade Review, 19(2), 216-231.

Bown, Chad. (2005). Trade Remedies and World Trade Organization Dispute Settlement: Why Are So Few Challenged?. The Journal of Legal Studies. Vol. 34, pp. 515-555.

Chung, R. C., Ip, W.H., \& Chan, S.L. (2009). An ARIMA-Intervention Analysis Model for the Financial Crisis in China's Manufacturing Industry. International Journal of Engineering Business Management, 1, 5. https://doi.org/10.5772/6785

Desembrico, J.A. (2019). Studi Kasus Putusan Panel World Trade Organization antara Indonesia dengan Amerika Serikat dalam Perkara Anti Dumping dan Tindakan Countervailing Sebagian Produk Coated Paper [Skripsi]. Jember: Repository Unej.

Enders, W. (2004). Applied Econometric Time Series Second Edition. New York: John Wiley \& Sons, Inc.

Forbil Institute. (2017). Mengenal dan Memahami Ekspor Hasil Hutan di Masa Industri 4.0. 10 Januari 2020. https://forbil.org/id/article/122/menge nal- dan-memahami-eksporhasil-hutan-di-masa-industri-40

Forest Watch Indonesia. (2014). Potret Keadaan Hutan Indonesia. 10 Januari $2020 . \quad$ http://fwi.or.id/wpcontent/uploads/2014/12/PKHI-20092013 update.pdf

Gujarati, D. N., Porter, D. C., \& Gunasekar, S. (2012). Basic econometrics. Tata McGraw-Hill Education.

International Monetary Fund. (2010). World Economic Outlook: Recovery, Risk, and Rebalancing. Washington: IMF

Kementerian Lingkungan Hidup dan Kehutanan. (2018). Data dan Informasi Pemetaan Tematik Kehutanan Indonesia. Booklet Pemetaan Tematik Kehutanan Indonesia. Jakarta: Kementerian Lingkungan Hidup dan Kehutanan.
Kementerian Perdagangan. (2015). Market Brief Indonesian Trade Promotion Center-Mexico City, Kertas. 2 Februari $2020 \quad$ melalui http://djpen.kemendag.go.id/member ship/data/files/1cc5e-kertas-final.pdf

Kementerian Perdagangan. (2018). Warta Pengkajian Perdagangan, Edisi II (16). Badan Pengkajian dan Pengembangan Perdagangan Kementerian Perdagangan.

Kementerian Perdagangan. (2019). Kemendag Gencarkan Perjanjian Dagang dengan Pasar Nontradisional.

https://www.kemendag.go.id/en/news room/media-corner/kemendaggencarkan-perianjian-dagangdengan-pasar-nontradisional

Kementerian Perindustrian. (2018). Berita Industri. Jakarta: Kementerian Perindustrian.

Krugman, P., \& Wells, R. (2010). World Economic Outlook, April 2009: Crisis and Recovery.

Lee, M.H., et al. (2010). Multi Input Intervention Model for Evaluating the Impact of the Asian Crisis and Terrorist Attacks on Tourist Arrival. Matematika 2010. Vol. 26 (1), pp. 83106.

Maspupah. (2013). Dampak Kebijakan Ekspor Rotan terhadap Ekspor Mebel Rotan Indonesia tahun 2000-2012 dengan Pemodelan ARIMA Intervensi [Skripsi]. Jakarta: Sekolah Tinggi Ilmu Statistik.

Neter, J., Wasserman, W., \& Kutner, M. H. (1989). Applied linear regression models. Boston: Richard D. Irwin, Inc.

Ningrum, A. W.P. (2006). Analisis Permintaan Ekspor Pulp dan Kertas Indonesia [Skripsi]. Bogor: Institut Pertanian Bogor.

Safitri, D. (2014). Analisis Daya Saing Komoditas Pulp dan Kertas Indonesia di Negara Importir Utama [Skripsi]. Bogor: Institut Pertanian Bogor. 
Sari, R. N., Mariani, S., Hendikawati, P. (2016). Analisis Intevensi Fungsi Step pada Harga Saham (Studi Kasus Saham PT Fast Food Indonesia Tbk). UNNES Journal of Mathematics. Vol. 5 (2), pp. 181-189. https://doi.org/10.15294/uim.v5i2.131 $\underline{31}$

Susila, W.R. \& Saputri, A.S. (2018). Bertahan dari Ancaman Kebijakan Trade Remedy. Warta Pengkajian Perdagangan, Badan Pengkajian dan Pengembangan Perdagangan. Vol. 2 (16), pp. 27-30. Jakarta: Kementerian Perdagangan

Unnikrishnan, Jyothi \& Suresh, Kodakanallur K. (2016). Modelling the Impact of Government Policies on Import on Domestic Price of Indian
Gold Using ARIMA Intervention Method. International Journal of Mathematical Sciences. 5 Februari 2020.

https://doi.org/10.1155/2016/6382926

Wei, W.W.S. (2006). Time Series Analysis: Univariate and Multivariate Methods, Second Edition. Boston: Pearson Addision Wesley, Inc.

Zhu, S., Turner, J.A., \& Buongiorno, J. (2008). Long-Term Economic Impact of Countervailing Duties on Coated Free Sheet Paper Imported by the United States from China, The Republic of Korea, and Indonesia. Forest Products Journal. Vol. 58 (10): 71-77, 58(10), 71-77. 